\title{
Impact of Service Quality on Patient Satisfaction: In a Public Hospital in Cap Vert
}

\author{
Amândio Baía ${ }^{1^{*}} \quad$ Teresa Baptista ${ }^{2}$ \\ 1.School of Tecnology and Management - Guarda Polytechnic - Portugal \\ UDI -Research Unit for Inland Development \\ 2.Master in Management - Cap Vert \\ * E-mail of the corresponding author: baia@ipg.pt
}

\begin{abstract}
Patient satisfaction is recognized as one of the most important quality dimensions and key success indicators in the health care industry. Identifying the most critical factors in hospitals related to the service quality will ensure survival and success in the future. This study aims to investigate patients' perception of the service quality provided by a public hospital in Cap Vert and propose some improvement measures. A questionnaire adapted from the ServPerf model was used to measure the patient's level of satisfaction. The findings of this study stated that all the dimensions namely reliable, responsiveness, assurance, empathy and tangibles are significantly related to the patient's satisfaction. Besides, the study also found that older patients, with less literacy and the ones with a greater number of children, feel more satisfied. Overall the perception of the patients about the service quality provided by the hospital and it's the satisfaction is quite poor. A report has been presented to the hospital administration, including results and suggestions in compliance with the findings.
\end{abstract}

Keywords: Service Quality, Satisfaction, ServPerf, ServQual, Public Hospital, Cap Vert

DOI: $10.7176 / \mathrm{EJBM} / 12-27-01$

Publication date:September $30^{\text {th }} 2020$

\section{Introduction}

Patients are considered customers of the hospital so, they expect high-quality services. The satisfaction of the patient is depended on the service performance which has been performed by the hospital. Hospital services are critical because life is a supreme value. To sustain in this dynamic environment where customer preferences are changing frequently due to easy accessibility and availability of information, the service providers must be proactive to the changing pattern of customer likes and dislikes.

Hospitals are one of the most important facilities providing healthcare services all over the world. The quality and cost-effectiveness of healthcare delivered are major issues to be continuously improved to have higher patient satisfaction (Carraher \& Carraher, 2006; Rahimi et al., 2014).

In the environments where there is no competition, that's to say when demand surpasses the supply, hospitals offer their patients unsatisfactory services because of the idea that the patients have no other alternatives and they would accept the present services unconditionally (Sahoo \& Ghosh, 2016). In the healthcare industry, hospitals provide the same types of service but they are differentiated based on the quality of service (Chaniotakis \& Lymperopoulos, 2009). Sadeh (2017) noted that the customer's satisfaction reflects the patients' attitude in the hospital environment.

The emotional response of a customer to the evaluation on the quality of the health service during the healthseeking experience is based on his/her basic knowledge about the healthcare services (Linqvist Leonardsen et al., 2016). The satisfaction level of customers towards the health services provided reflects the quality of service which in turn may create loyalty among customers to the service and the place (Xesfingi \& Vozikis, 2016). The customer deserves respect and appreciation as the main focus of the organization in such a way that the health service quality of the provider can be reflected in the health-seeking behaviour of the customer (Maria Stock et al., 2017).

In a developing country like Cap-Vert where the healthcare sector is heavily subsidized but even so does not receive appropriate funding, as compared to other nations, the effective management of healthcare organization is very critical. Both, the service quality and patient's satisfaction have significant consideration in healthcare organizations because this is crucial for their strategic decisions. Perception of patients about hospitals affects the profitability, as well as image extensively influenced the hospitals' reputation, with patients' word-of-mouth and trust (Shabbir, Kaufmann \& Shehzad 2016). The increased patients' satisfaction helps hospitals' management in terms of money and reduces time in managing patients' complaints. In this way, it is highly essential to identify the factors which satisfy the customers and strategize policies based on these requirements.

Within the health care system, developing countries have sufficiently explored the direct link between patient satisfaction and process design, mapping, and improvement, but there are minimal studies on patients' satisfaction in developing countries (Alexander et al, 2016; Al Khani, 2015).

This research intends to determine the impact of service quality on customer satisfaction as Cap-Vert citizens who receive healthcare from a public hospital, Hospital Baptista de Sousa (HBS) and need the best health care 
services. By determining the significant variables influencing outpatients' satisfaction, this study gives an insight for managers and staff of public hospitals on the effect of service quality towards outpatients' satisfaction and also recommends ways for its improvement.

\section{Literature Review}

All hospitals have found it necessary to measure, monitor, and improve the quality of healthcare services to survive and achieve patient satisfaction (Punnakitikashem, Buavaraporn, \& Leelartapin, 2012). Many types of research have been conducted to assess service quality in hospitals and other healthcare organizations worldwide (NekoeiMoghadam \& Amiresmaili, 2011; Aghamoulaei, Zare \& Kebriaei, 2008; Tabibi, Gohari \& Shahri, 2012; Sohail, 2003; Karassavidou \& Papadopoulos, 2009; Anbori, Ghani, \& Yadav, 2010; Çaha, 2007; Al Momani, 2012; Figen \& Ebru, 2010).

\subsection{Service Quality}

Healthcare is a leading issue for contemporary society so healthcare managers need a thorough understanding of the ways to increase the quality of care in practical terms.

Nowadays, the demand for quality health care is a leading issue in the world that is increasing (Huang, Lai, $\mathrm{Hu}, \&$ Weng, 2014). Therefore, it is necessary to analyse the quality of hospital services for quality health care. Conceptualising and measuring the quality of hospital services, as a service system, directly influence public health (Rasouli \& Zarei, 2015) although are complex (Um and Lau, 2018). Measuring quality implies selecting and adopting some evidence-based criteria that include client satisfaction with the service they receive (Mendes et al., 2018). There is evidence that patient perceptions of health service quality strongly influence their choice of healthcare provider (Handayani et al., 2015; Rashid \& Jusoff, 2009). Given that the health providers need to gather information on patient needs, expectations and perceptions to adjust their services to patients rather than make their patients fit their services (Qin et al., 2015; Ramsaran-Fowdar, 2005).

Service quality improvement can be possible by focusing the dissatisfactions in patients' hospital assessments as well. Reducing patient dissatisfaction in-hospital services is quite important for patients and decision-makers as well. Dissatisfaction affects patient loyalty to the service provider (Fatima et al., 2018; Rostami et al., 2019; Shabbir et al., 2016). Decreasing patient dissatisfaction level leads to positive perceptions by patents and influences the competitive power of the hospitals positively.

Measuring customer satisfaction is something broader and intangible and evaluating the quality of the service provided boils down to specific dimensions of the service (Falcão et al., 2017).

\subsection{Customer Satisfaction}

Customer satisfaction is a common term in numerous fields including marketing and finance (Fornell \& Larcker, 1981; Yi \& Nataraajan, 2018). Customer satisfaction is referred to the application of some procedures to bridge the gap that exists between the needs and expectations of a client and available products and services (Linqvist Leonardsen et al., 2016; Sadeh, 2017; Xesfingi \& Vozikis, 2016). Customer satisfaction can be described as the attitude or the opinion of a person concerning aspects of health services according to previous experience (Sahoo \& Ghosh, 2016).

Many researchers discussed customer satisfaction and attempted to improve their definition. As stated by Swies et al. (2017), customer satisfaction refers to attaining the provision needed by the customer. Satisfaction is a situation that occurs as a result of the customer's relationship with the organization over some time (Izogo \& Ogba, 2015). According to Maria Stock et al. (2017), satisfaction is the consumers' assessment of a product or service in respect of whether their expectations and needs are met with regards to those products or services.

Satisfaction influences patient recommendations positive (McCall et al., 2016). Satisfaction is considered as a positive and emotional state determined through the assessment of all facets of the customer's relationship with the organization (Al-Abri \& Al-Balushi, 2014). The major focus of an organization is customer satisfaction since it reflects the nature of services of products produced for the customers (Lagrosen \& Lagrosen, 2016). Low satisfaction levels among patients are associated with a lack of trust in health institutions (Maria Stock et al., 2017; Züllich et al., 2012).

One of the most widely researched tools for increasing patient's satisfaction is ServQual model, developed by Parasuraman, Zeithmal, and Berry (1988). It is one of the best and most used models for evaluating customer expectations and their perceptions of the quality of services since it has flexibility, which makes it possible to be modified by the researcher according to the nature of the institution without changing its five-dimensional structure (Ali \& Raza, 2017; Awang et al., 2015; Anbari \& Tabaraie, 2013). It relies on the idea that quality is a subjective evaluation of the customer and suggests that five dimensions alter patient's perceptions about the quality of services offered by a hospital. Dimension reliability refers to the consistency and dependability of the hospital to offer promised services to their patients. Responsiveness refers to the provision of services promptly. Assurance represents the knowledge, skills and abilities of staff in establishing rapport and trust with patients for the services 
provided. Empathy represents the extent to which healthcare providers offer extended emotional support to their patients. Finally, tangibles refer to structural or facility-related elements. As the health care staff meets the expectation of patients, patient satisfaction will increase (Amole et al., 2015).

Cronin and Taylor (1992) proposed, as an alternative, the ServPerf model, which has the same dimensions as ServQual, as it only uses patient perceptions to evaluate service quality.

Many types of research have measured service quality at different hospitals using different methodologies. Paul (2003) performed a comparison between the two prevalent service quality models, ServQual and ServPerf, and applied it in the setting of periodontists. He concluded that ServPerf without importance weights appears to be a better measure of service quality in periodontists. Gurbuz, et al. (2008) explained the reason of incompetency of ServQual scale that the consumers do not know about expectation related to service before they receive the service. They even do not know what to expect.

To sustain the advantage and be ahead of their rivals' organisations must focus on customers' needs and demands by fulfilling customer's expectations with improved service quality (Klementova, Zavadsky, \& Zavadska, 2015; Martins, de Carvalho, Ramos, \& Fael, 2015).

\section{Methodology}

This study focuses on the effect of service quality on outpatients' satisfaction in the public hospital - Hospital Baptista Sousa (HBS), San Vicent Isle, in Cap-Vert which is a developing country. The hospital treats, on average, 2272 patients every day.

As a research instrument, a questionnaire-based in the ServPerf scale, slightly modified to suit the specific features of the HBS, was used (El-Toamy et al., 2015; Izogo \& Ogba, 2015; Saleh, 2017).

The survey questionnaire consisted of two sections. The first section includes questions to determine the sociodemographic profiles (gender, age, educational level, marital status, professional activity, number of children, medical visits (last year), knowledge of the complaints book and complaints). The second section of the questionnaire was a 23-item scale measuring the dimensions (Reliability, Responsiveness, Assurance, Empathy and Tangibility) of service quality. In this section respondents were required to rate on a 5-point Likert scale for data collection with " 1 " as "strongly disagree" and " 5 " as "strongly agree".

The questionnaire was pilot tested by ten patients who visited the hospital. Respondents in the pilot test did not have problems with the questionnaire, although minor changes of the wording were suggested. The research questionnaire was in Portuguese and face-to-face interviews were conducted to ensure a high response rate and to reduce the missing data in the questionnaires. Subjects were asked to assess items of the different dimensions and the overall satisfaction.

A convenience sample of patients, age 18 and up, who had been treated in the various departments of HBS hospital in 2018, was used. Thus, the research design is a cross-sectional, one sample at a one-time point. There were collected 413 valid questionnaires. In determining the sample size, we had a significance level of 5\% and a sampling error of $4.77 \%$.

Based on the literature on satisfaction assessment models, we designed a conceptual research model presented in Figure 1 to teste the impact of the service quality on customer satisfaction.

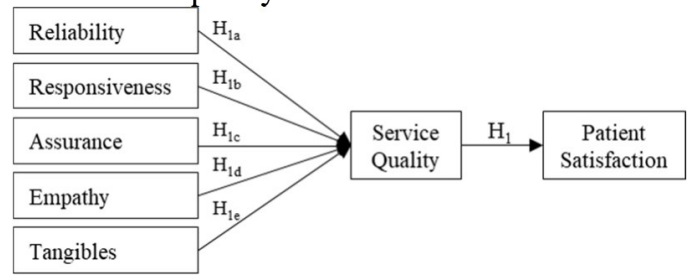

Figure 1 - Conceptual research model

In consequence, the following hypothesis provided the scope and depth of the study were formulated:

H1: All the five-service quality-related dimensions have a significantly positive influence on patient satisfaction. H2: Age, Gender, Educational Level, Marital Status, Professional Activity, Number of Children, Number of Medical Visits (per year), Knowledge of the Complainants' Book and You already complained, impacts the evaluations of the service quality and satisfaction by the patients.

To improve the outpatients' satisfaction item responses were classified as green if its average $>4$, yellow if its $3 \leq$ average $\leq 4$ and red if its average $<3$. Items classified red need special action measures and immediate intervention to be improved. Yellow items need attention to improve to green. Green items need to be stimulated to be maintained and improved.

To test the consistency of the sample, the Kaiser-Meyer-Olkin test (KMO) was used. The reliability of the dimensions and the questionnaire, in general, was calculated using the Cronbach's alpha coefficient.

To assess of group average differences of the contextual variables related to the outpatients' satisfaction oneway ANOVA, the Mann-Whitney U test, and the Kruskal-Wallis non-parametric, followed by multiple 
comparisons of the order means with ANOVA Tukey, as described by Maroco (2018) were used.

All statistical work was performed on IBM SPSS software (v25 - SPSS Inc Chicago, IL) and Excel (Microsoft Office 2015, Microsoft Corporation).

\section{Results}

The socio-demographic profile of the 413 respondents is described in Table 1 . The majority of the respondents are female $(54.72 \%), 74.33 \%$ have less than 45 years of age, $35.11 \%$ has the secondary as the Educational Level, $77.24 \%$ are unmarried, $28.33 \%$ work in the private sector, $49.64 \%$ have 3 or fewer children, $56.66 \%$ went last year between 1 and 3 visits to the hospital, 59.08\% didn't know the existence of the complaints book and just $4.6 \%$ already complained.

Table 1 - Socio-Demographic Profile of Respondents

\begin{tabular}{|c|c|c|c|}
\hline Category & Items & Frequency & $(\%)$ \\
\hline \multirow{2}{*}{ Gender } & Male & 187 & 45.28 \\
\hline & Female & 226 & 54.72 \\
\hline \multirow{4}{*}{ Age (years) } & $18-30$ & 165 & 39.95 \\
\hline & $31-44$ & 142 & 34.38 \\
\hline & $45-60$ & 75 & 18.16 \\
\hline & +60 & 31 & 7.51 \\
\hline \multirow{7}{*}{ Educational Level } & 1st Cycle & 64 & 15.50 \\
\hline & 2nd Cycle & 93 & 22.52 \\
\hline & Secondary & 145 & 35.11 \\
\hline & Bachelor & 17 & 4.12 \\
\hline & Graduate & 84 & 20.34 \\
\hline & Master & 8 & 1.94 \\
\hline & $\mathrm{PhD}$ & 2 & 0.48 \\
\hline \multirow{4}{*}{ Marital Status } & Not Married & 319 & 77.24 \\
\hline & Married & 60 & 14.53 \\
\hline & Widow & 19 & 4.60 \\
\hline & Divorced & 12 & 2.91 \\
\hline \multirow{7}{*}{$\begin{array}{l}\text { Professional } \\
\text { Activity }\end{array}$} & Public Sector Employee & 60 & 14.53 \\
\hline & Private Sector Employee & 117 & 28.33 \\
\hline & Business Man & 5 & 1.21 \\
\hline & Retired & 25 & 6.05 \\
\hline & Unemployed & 73 & 17.68 \\
\hline & Student & 76 & 18.40 \\
\hline & Other & 57 & 13.80 \\
\hline \multirow{4}{*}{ Number of Children } & None & 141 & 34.14 \\
\hline & $1-3$ & 205 & 49.64 \\
\hline & $4-7$ & 55 & 13.32 \\
\hline & +7 & 12 & 2.91 \\
\hline \multirow{3}{*}{$\begin{array}{l}\text { Medical } \\
\text { (year) }\end{array}$} & $1-3$ & 234 & 56.66 \\
\hline & $4-7$ & 116 & 28.09 \\
\hline & +7 & 63 & 15.25 \\
\hline \multirow{2}{*}{$\begin{array}{l}\text { Knowledge of the } \\
\text { Complaints' Book }\end{array}$} & Sim & 169 & 40.92 \\
\hline & Não & 244 & 59.08 \\
\hline \multirow{2}{*}{$\begin{array}{l}\text { You already } \\
\text { complained }\end{array}$} & Sim & 394 & 95.40 \\
\hline & Não & 19 & 4.60 \\
\hline
\end{tabular}

As can be seen in Table 2, 17 items (73.91\%) of the Service Quality dimensions had a red classification. Half of the yellow items belong to the Tangibles dimension. All the reliability items belonged to the red classification. Although the overall patient's perception of the service quality is quite poor (mean=2.81), it should be emphasized the all the items related to doctors' service laid in the yellow classification. 
Table 2 - Mean and Standard Deviation of the Dimensions' Items

\begin{tabular}{lrr}
\hline \multicolumn{1}{c}{ Variables } & Mean & $\begin{array}{c}\text { Standard } \\
\text { Deviation }\end{array}$ \\
\hline Reliability & 2,57 & 0,945 \\
Does the hospital perform the services on time? & 2,51 & 1,188 \\
Is hospital service performed as promised? & 2,59 & 1,138 \\
How do you equate hospital office hours? & 2,37 & 1,258 \\
Are staff competent to solve customer / patient problems? & 2,81 & 1,162 \\
\hline \multicolumn{1}{c}{ Responsiveness } & 2,56 & 0,904 \\
How do you consider hospital care? & 2,55 & 1,126 \\
Is there objectivity of the information provided to clients / patients? & 2,79 & 1,143 \\
Easy appointment bookings? & 2,33 & 1,292 \\
Degree of satisfaction with the medical care received? & 3,18 & 1,130 \\
Waiting time regarding appointments, exams and treatments? & 1,95 & 1,188 \\
\hline Assurance & 2,93 & 0,945 \\
Do employees convey security to clients / patients? & 2,84 & 1,174 \\
Does the hospital have civilized and correct staff? & 2,87 & 1,198 \\
How do you rate hospital comfort and safety? & 2,90 & 1,211 \\
Do Doctors provide security to their clients / patients during consultations? & 3,35 & 1,138 \\
Does HBS generally respect the rights and duties of clients / patients? & 2,69 & 1,169 \\
\hline Empathy & 2,86 & 0,907 \\
Do you recommend hospital services to relatives and friends? & 2,72 & 1,230 \\
Satisfaction with the cost of services provided? & 2,77 & 1,192 \\
Are the staff cordial and kind? & 2,80 & 1,117 \\
Are doctors friendly and kind? & 3,18 & 1,148 \\
Are appointment times convenient for clients / patients? & 2,85 & 1,178 \\
\hline Tangibles & 3,12 & 0,909 \\
How do you rate hospital equipment? & 3,03 & 1,143 \\
How do you rate the hospital facilities? & 2,94 & 1,112 \\
As you classify, hygiene and hospital cleanliness? & 2,97 & 1,148 \\
The staff are well presented and clean? & 2,54 & 1,082 \\
\hline Service Quality & 2,79 & 0,805 \\
\hline
\end{tabular}

The Kaiser-Mayor-Olkin (KMO) measure of sampling adequacy was 0.939 and the Cronbach's $\alpha$ was 0.951 being that all dimensions are superior to 0.70 (Table 1) meaning that the questionnaire's reliability (Parsian \& Dunning, 2009) and validity were deemed effective (Table 3 ).

Table 3 - Reliability Statistics

\begin{tabular}{lrr}
\hline \multicolumn{1}{c}{ Construct } & Number of Items & Cronbach Alfa \\
\hline Reliability & 4 & 0.807 \\
Responsiveness & 5 & 0.826 \\
Assurance & 5 & 0.861 \\
Empathy & 5 & 0.831 \\
Tangibles & 4 & 0.826 \\
Questionnaire & 24 & 0.951 \\
\hline
\end{tabular}

Scores for the five dimensions showed a positive correlation with each other (Table 4), meaning that the dimensions all made an approximately equal contribution to the overall ServPerf assessment.

Table 4 - Pearson Correlation Matrix of the Five Dimensions

\begin{tabular}{|c|c|c|c|c|c|c|c|c|c|}
\hline \multirow{2}{*}{ Reliability } & \multicolumn{2}{|c|}{ Reliability } & \multicolumn{2}{|c|}{ Responsiveness } & \multicolumn{2}{|c|}{ Assurance } & \multicolumn{2}{|c|}{ Empathy } & Tangibles \\
\hline & \multirow[b]{2}{*}{0.658} & $\begin{array}{l}1 \\
\left(R^{2}=\right.\end{array}$ & & \multirow{2}{*}{\multicolumn{2}{|c|}{1}} & & & \\
\hline Responsiveness & & $\begin{array}{l}0.433) \\
\left(\mathrm{R}^{2}=\right.\end{array}$ & & $\begin{array}{l}1 \\
\left(R^{2}=\right.\end{array}$ & & & & & \\
\hline Assurance & 0.572 & $\begin{array}{l}0.327) \\
\left(\mathrm{R}^{2}=\right.\end{array}$ & 0.732 & $\begin{array}{l}0.536) \\
\left(\mathrm{R}^{2}=\right.\end{array}$ & & $\left(\mathrm{R}^{2}=\right.$ & & 1 & \\
\hline Empathy & 0.640 & $\begin{array}{l}0.410) \\
\left(R^{2}=\right.\end{array}$ & 0.723 & $\begin{array}{l}0.523) \\
\left(\mathrm{R}^{2}=\right.\end{array}$ & 0.795 & $\begin{array}{l}0.632) \\
\left(R^{2}=\right.\end{array}$ & & $\left(\mathrm{R}^{2}=\right.$ & 1 \\
\hline Tangibles & 0.524 & $0.275)$ & 0.574 & $0.329)$ & 0.714 & $0.510)$ & 0.739 & $0.546)$ & \\
\hline
\end{tabular}

Correlations is significant at the 0.01 level (2-tailed test)

Table 5 shows that $\mathrm{R}^{2}=0.891$ meaning that $89.10 \%$ of the change in the dependent variable outpatient's 
satisfaction, can be explained by the five independent variables, namely, reliability, responsiveness, assurance, empathy and tangibles. The F value is equal to $667.719(\mathrm{p}<0.001)$ which shows that the Multiple Linear Regression is significant and at least one of the five dependent variables has a significant relationship with the outpatient's satisfaction. Therefore, the proposed conceptual framework model fits.

The Standardized Regression Model is: Outpatient Satisfaction=0.258 (Reliability) +0.213 (Responsiveness) +0.233 (Assurance) +0.163 (Empathy) +0.240 (Tangibles)

All the ServPerf dimensions have a significant positive effect on outpatient' satisfaction and thus the whole hypothesis is supported. Reliability $(\beta=0.258)$ and tangibles $(\beta=0.240)$ most strongly predict the perception of outpatient satisfaction.

Table 5 - Construct Parameter Estimates

\begin{tabular}{lcccccrr}
\hline \multicolumn{1}{c}{ Predictor variable } & $\mathrm{B}$ & $\mathrm{SE}$ & $\mathrm{B}$ Bta & $\mathrm{t}$ & $\mathrm{l}$ Sig & Hypothesis & Remarks \\
\hline Intercept & -0.122 & 0.054 & & -2.264 & 0.024 & - & - \\
Reliability & 0.236 & 0.021 & 0.258 & 11.253 & 0.000 & $\mathrm{H} 1$ & Supported \\
Responsiveness & 0.204 & 0.026 & 0.213 & 7.818 & 0.000 & $\mathrm{H} 2$ & Supported \\
Assurance & 0.213 & 0.028 & 0.233 & 7.643 & 0.000 & $\mathrm{H} 3$ & Supported \\
Empathy & 0.156 & 0.030 & 0.163 & 5.110 & 0.000 & H4 & Supported \\
Tangibles & 0.229 & 0.024 & 0.240 & 9.396 & 0.000 & H5 & Supported
\end{tabular}

$\mathrm{R}=0.944 ; \mathrm{R}^{2}=0.891 ;$ Adjusted $\mathrm{R}^{2}=0.890 ; \mathrm{F}=667.719(\mathrm{p}<0.001)$

As hypothesised, there is a significant positive relationship between the service quality dimensions and outpatient's satisfaction, thus all the hypothesis were supported. The results are in line with other findings:

Reliability - Essiam (2015) and Zaim et al. (2010) concluded that the higher the ability to perform services accurately and dependably the higher the level of outpatient's satisfaction. Also are in line with the findings of Yousapronpaiboon and Johnson (2015) that health care providers who give proper explanations to outpatients would influence outpatient satisfaction.

Responsiveness - Yousapronpaiboon and Johnson (2015), Amole et al. (2015) found that past experiences with health care services could influence a patient's expectations of services.

Assurance - Hassali et al. (2014), who evidenced that the quality of the health care services provided affects patient's confidence in the skills of health care provided and Abioye et al. (2010), who stated that clear understandable information and/or explanation provided by health care staff to outpatients would lead to higher levels of outpatient's satisfactions.

Empathy - the results of Zaim et al (2010) and Van De Ven (2014) were confirmed. Although the HBS is a public hospital where the service is given free of charge by the government, the outpatients expected polite staff, give supports and shows concern with the patient's problems.

Tangibles - Alshatnawi and Ambus (2016), Pouragha and Zarei (2016) stated that hospitals with good infrastructures and equipment as well as neatly attired personnel that are visually appealing can attract patients since a positive perception of the hospital is created. Thus, tangibility encourages patients to visit hospitals with such environments for treatment.

To improve the service quality provided by the HBS and leave some recommendations, we tried to find significant differences in the factors, gender, age, educational level, marital status, professional activity, number of children, medical visits per year, knowledge of the claiming book and complainants, related to each of the five dimensions of the ServPerf model.

The analysis revealed no significant differences associated with gender, knowledge of the claiming book, complainants (Mann-Whitney test, $\mathrm{p}>0.05$ ), marital status, professional activity and medical visits per year (Kruskal-Walls test, $\mathrm{p}>0.05$ ). In contrast, there were found significant differences in other factors.

Age was a highly significant variable. Patients with more than 60 years of age showing higher satisfaction then those of the other age echelons in all the dimensions - Kruskal-Wallis non-parametric (Table 6), followed by multiple comparisons of the order means with ANOVA Tukey, as described by Maroco (2018) (Table 7).

The results of Sadeh (2017) were confirmed only in the part that, older customers' satisfaction with health care is higher than younger customers. However, in this study no significant difference in satisfaction among gender were found. 
Table 6 - Kruskal-Wallis and ANOVA test - Dimensions versus Age

\begin{tabular}{lllcc}
\hline & \multicolumn{2}{c}{ Kruskal-Wallis } & \multicolumn{2}{c}{ ANOVA one way } \\
\hline \multicolumn{1}{c}{$\chi^{2}$} & $\mathrm{P}$ & $\mathrm{Z}$ & $\mathrm{p}$ \\
\hline Reliability & 17.092 & $0.001^{*}$ & 6.948 & $0.000^{*}$ \\
Responsions & 16.760 & $0.001^{*}$ & 7.093 & $0.000^{*}$ \\
Assurance & 23.834 & $0.000^{*}$ & 9.481 & $0.000^{*}$ \\
Empathy & 16.113 & $0.001^{*}$ & 7.740 & $0.000^{*}$ \\
Tangibles & 22.066 & $0.000^{*}$ & 8.296 & $0.000^{*}$ \\
\hline
\end{tabular}

* Significant at the 0.01 level

Table 7 - Tukey HSD test- Dimensions versus Age

\begin{tabular}{lccc}
\hline Age: $+60(\mathrm{I})$ & $\mathrm{J}$ & $\mathrm{I}-\mathrm{J}$ & $\mathrm{p}$ \\
\hline Reliability & $18-30$ & $0.81266^{*}$ & 0.000 \\
& $31-44$ & $0.61239^{*}$ & 0.005 \\
& $45-60$ & $0.71054^{*}$ & 0.002 \\
\hline Responsiveness & $18-30$ & $0.77564^{*}$ & 0.000 \\
& $31-44$ & $0.76088^{*}$ & 0.000 \\
& $45-60$ & $0.69273^{*}$ & 0.002 \\
\hline Assurance & $18-30$ & $0.77677^{*}$ & 0.000 \\
& $31-44$ & $0.78128^{*}$ & 0.000 \\
& $45-60$ & $1.04077^{*}$ & 0.000 \\
\hline Empathy & $18-30$ & $0.79241^{*}$ & 0.000 \\
& $31-44$ & $0.64780^{*}$ & 0.001 \\
& $45-60$ & $0.82951^{*}$ & 0.000 \\
\hline Tangibles & $18-30$ & $0.74335^{*}$ & 0.000 \\
& $31-44$ & $0.60370^{*}$ & 0.004 \\
& $45-60$ & $0.90366^{*}$ & 0.000 \\
\hline
\end{tabular}

* Average difference is significant at 0.05 level

The variable Educational Level has only a significant difference with the dimension responsiveness (Table 8 and 9). The respondents with 1 st cycle education are more satisfied with the dimension responsiveness than the ones with the holders of the secondary level education.

Table 8 - Kruskal-Wallis and ANOVA test - Dimensions versus Educational Level

\begin{tabular}{ccccc}
\hline & \multicolumn{2}{c}{ Kruskal-Wallis } & \multicolumn{2}{c}{ ANOVA one way } \\
Dimensions & $\chi 2$ & $\mathrm{P}$ & $\mathrm{Z}$ & $\mathrm{p}$ \\
\hline Responsiveness & 13.602 & 0.034 & 2.272 & 0.036 \\
\hline
\end{tabular}

* Significant at the 0.05 level

Table 9 - Tukey HSD test- Dimensions versus Educational Level

\begin{tabular}{lccc}
$1^{\text {st }}$ Cycle (I) & J & I - J & p \\
\hline Responsiveness & Secondary & $0.46636^{*}$ & 0.010 \\
\hline
\end{tabular}

$*$ Average difference is significant at 0.05 level

The variable Number of Children had a significant effect on all the dimensions (Table 2 and 3 ). In general, the respondents with four or more children are more satisfied in all dimensions than the one with less than three children. These results are aligned with the ones related to the variable Age considering that the older respondents also have more children (for example the totality of respondents with more than seven children have more than forty-five years).

Table 9 - Kruskal-Wallis and ANOVA test - Dimensions versus Number of Children

\begin{tabular}{lllcc}
\hline & \multicolumn{2}{c}{ Kruskal-Wallis } & \multicolumn{2}{c}{ ANOVA one way } \\
\hline \multicolumn{1}{c}{ Dimensions } & $\chi 2$ & $\mathrm{p}$ & $\mathrm{Z}$ & $\mathrm{p}$ \\
\hline Reliability & 14.803 & 0.002 & 5.399 & 0.001 \\
Responsiveness & 23.065 & 0.000 & 8.444 & 0.000 \\
Assurance & 18.031 & 0.000 & 6.024 & 0.001 \\
Empathy & 20.187 & 0.000 & 7.382 & 0.000 \\
Tangibles & 12.201 & 0.007 & 3.676 & 0.012 \\
\hline
\end{tabular}

* Significant at the 0.05level 
Table 10 - Tukey HSD test- Dimensions versus Number of Children

\begin{tabular}{llll}
\hline & \multicolumn{1}{c}{$\mathrm{J}$} & $\mathrm{I}-\mathrm{J}$ & $\mathrm{p}$ \\
\hline Reliability & None & $1.00798^{*}$ & 0.002 \\
[Children + 7 (I)] & $1-3$ & $1.04654^{*}$ & 0.001 \\
& $4-7$ & $0.81439^{*}$ & 0.032 \\
\hline Responsiveness & & & \\
{$[$ Children 4-7 (I)] } & None & $0.36660^{*}$ & 0.045 \\
& $1-3$ & $0.38235^{*}$ & 0.023 \\
{$[$ Children +7 (I)] } & None & $1.09539^{*}$ & 0.000 \\
& $1-3$ & $1.11114^{*}$ & 0.000 \\
& $4-7$ & $0.72879^{*}$ & 0.048 \\
\hline Assurance & & & \\
[Children + 7 (I)] & None & $0.87766^{*}$ & 0.010 \\
& $1-3$ & $1.00984^{*}$ & 0.002 \\
\hline Empathy & & \\
[Children 4-7 (I)] & None & $0.42721^{*}$ & 0.014 \\
& $1-3$ & $0.37792^{*}$ & 0.027 \\
[Children +7 (I)] & None & $0.99539^{*}$ & 0.001 \\
& $1-3$ & $0.94610^{*}$ & 0.002 \\
\hline Tangibles & & \\
{$[$ Children 4-7 (I)] } & None & $0.42505^{*}$ & 0.017 \\
\hline Average difference is significant at 0.05 level &
\end{tabular}

In sum, the overall service quality perceived by patients was quite bad. Although Cap- Vert is a developing country, where there is careful respect for the human being, the HBS needs to implement regulatory policies to provide better services for patients.

Thus, to improve the service quality provided by the HBS and consequently the satisfaction it is highly essential to identify the factors which satisfy the customers and strategize policies based on these requirements.

\section{Suggestions and Recommendations}

- Deepen efforts to reduce waiting times concerning appointments, examinations and treatments.

- Make the appointments available via digital.

- Disclose the existence of the complaint book and sensitize users/patients to its use.

- Implement training processes, properly structured, in line with the real needs of workers to give them more skills on the provision of services, so that all those who use the services of this hospital are more satisfied. It is recalled that Satisfaction is a feeling of pleasure or disappointment resulting from the comparison of the expected performance of the service (or result) about customer expectations (Kotler, Keller, Ancarani, \& Costabile, 2016). This satisfaction is also reflected in the client's actions as the indication of the service to others (Ricci, Wanderley, Oliveira, \& Rebelatto, 2009).

- Create the HBS organization chart so that stakeholders understand the hierarchical and organizational structure of this institution.

- Improve the reporting process of HBS, in particular, that directed to users under 45 years of age to mitigate their dissatisfaction with the quality of services provided by this institution.

- $\quad$ Start a certification process supported, for example, in ISO 9001:2015 - Management System and /or ISO 14001 Standard - Environmental Management.

\section{Conclusions}

This study used the ServPerf model to explain the relationship between the service quality and outpatient's satisfaction toward the public hospital, Hospital Baptista de Sousa in Cap-Vert. The R-square value of 0.891 of the multiple regression model fit indicates that the ServPerf model with the five variables Reliability, Responsibility, Assurance, Empathy and Tangibles successfully provides the explanations about the influence of these service quality dimensions on the outpatient's satisfaction. Stated in another way, the quality of the services provided by HBS has a positive impact on the satisfaction of patients.

Only the tangibles dimension was classified as yellow. All the other service quality dimensions laid in the red classification, which implies that the perceived quality of health services provided by Hospital Baptista de Sousa has not been satisfying to patients and needed to be improved. In this way, the HBS should heard permanently the voice of the patients to improve the quality of the services provided.

It is important to relieve that they are the older patients, with a greater number of children and fewer educational qualifications who say they are more satisfied with the quality of services provided by HBS. It is also noteworthy that the average classification in all items associated with medical interventions has a yellow 
classification.

The limitation of this study is that it was performed in one particular establishment. Further research should attempt to replicate the study in other hospitals public or private. This study should also be repeated, shortly, to compare the evolution of patient satisfaction with the services provided by the Baptista de Sousa Hospital.

\section{References}

Abioye, K. E., I. S., Bello, T., Olaleye, I. A., \& Amedi, M. (2010). Determinants of patient satisfaction with physician interaction: A cross-sectional survey at the Obafemi Awolowo University Health Centre, Ile-Ife, Nigeria. South African Family Practice, 52(6): 557-562.Available at: https://doi.org/10.1080/20786204.2010.10874047.

Aghamoulaei, T. S., Zare, A., \& Kebriaei, A. (2008). Quality gap in primary health care services in Bandar Abbas: Woman's perspective. Payesh, 7 (2) (pp. 121-127.

Al Khani, R. (2015). Improving Waiting Time and Patients' Experience in a Medical Retina Clinic. Unpublished Master Thesis, Royal College of Surgeons in Ireland.

Al Momani, M. (2012). Patient experience of nursing quality in a Teaching Hospital in Saudi Arabia. Iran. $J$ Public Health, 41 (8) pp. 42-49.

Al-Abri, R., \& Al-Balushi, A. (2014). Patient satisfaction survey as a tool towards quality improvement. Oman Medical Journal, 29(1), 3.

Alexander, D., Abbott, L., Zhou, Q., \& Staff, I. (2016). Can Triage Nurses Accurately Predict Patient Dispositions in the Emergency Department? Journal of Emergency Nursing, 42(6), 513-518.

Ali, M., \& Raza, S. A. (2017). Service quality perception and customer satisfaction in Islamic banks of Pakistan: the modified SERVQUAL model. Total Quality Management \& Business Excellence, 28(5-6), 559-577.

Alshatnawi, H. A. M., \& Amlus, M. H. B. (2016). The influence of service quality on customer satisfaction: Evidence from public hospitals. International Journal for Research in Business, Management and Accounting, 2(1): 73-88

Amole, B. B., Oyatoye, E. O., \& Kuye, O. L.( 2015). Determinants of patient satisfaction on service quality dimensions in the Nigeria teaching hospitals. Economics Management Innovation, 7(3): 3-20.

Anbari, Z., \& Tabaraie, Y. (2013). Measurement of quality of hospital services via SERVQUAL model. Bulletin of Environment, Pharmacology and Life Sciences, 3(1), 51-6.

Anbori, A., Ghani, H., \& Yadav, A. (2010). Patient satisfaction and loyalty to the private hospitals in Sana'a. Yemen. Int $J$ Qual Health Care, 22 (4) pp. 310-315.

Awang, Z., Afthanorhan, A., Mohamad, M., \& Asri, M. A. M. (2015). An evaluation of measurement model for medical tourism research: the confirmatory factor analysis approach. International Journal of Tourism Policy, 6(1), 29-45.

Butt, M. M., \& de Run, C. E. (2010). Private healthcare quality: Applying a ServQual model. International Journal of Health Care Quality Assurance, 23(7): 658-673.

Çaha, H. (2007). Service quality in private hospitals in Turkey. J Econ Soc Res, 9 (1) pp. 55-69.

Carraher, S. M., Carraher, S. C. (2006). Enterprises C. Customer service, entrepreneurial orientation, and performance: A study in health care organizations in Hong Kong, Italy, New Zealand, the United Kingdom, and the USA. J Appl Manag Entrep. 11(4):33-48.

Chaniotakis, I. E., \& Lymperopoulos, C. (2009). Service quality effect on satisfaction and word of mouth in the health care industry, Managing Service Quality, Vol.19, Iss:2, pp.229-242.

Cronin, J. J. \& Taylor, S. A. (1992). Measuring service quality: a re-examination and extension. Journal of Marketing, Vol. 56, No. 3, pp.55-68 [online] https://journals.sagepub.com/toc/jmxa/56/3.

El-Tohamy, A. E. M. A., Raoush, A. T. Al., Albejaidi, F., Al-Shdaifat, E. A., Management, T. Q., Standards, U. A., ... Sallis, E. (2015). Total quality management. International Journal of Business and Social Research, 2(2), 51-56

Essiam, J. O. (2015). Service quality and patients satisfaction with healthcare delivery: Empirical evidence from patients of the outpatient department of a public university hospital in Ghana. European Journal of Business and Management, 5(28): 52-59.

Fatima, T., Malik, S. A. \& Shabbir, A. (2018). Hospital healthcare service quality, patients satisfaction and loyalty: an investigation in context of private healthcare systems. International Journal of Quality \& Reliability Management, Vol. 35, No. 6, pp.1195-1214, Emerald Publishing Limited.

Falcão, L. A., Jerônimo, T., Melo, F. C., Aquino, J. T., \& Medeiros, D. D. (2017). Using the Servqual Model to Assessmall Service Quality and Customer Satisfaction. Brazilian Journal of Operations and Production Management, 14, 82-88.

Figen, Y., \& Ebru, D. (2010). Health care service quality: A comparison of public and private hospitals. Afr $J$ Bus Manag, 4 (6) pp. 962-971.

Fornell, C., \& Larcker, D. F. (1981). Evaluating structural equation models withunobservable variables and 
measurement error. Journal of Marketing Research, 18(1), 39-50. doi:10.2307/3151312

Gurbuz, E., Buyukkeklik, A., Avcilar, M. Y., \& Toksari, M. (2008). Algilanan Hizmet Kalitesinin Tatmin ve Davranissal Niyet Uzerine Etkisi: Nigde İlindeki Supermarketler Uzerine Ampirik Bir Calisma. Ege Akademik Bakis, 8(2), 785-812.

Handayani, P. W., Hidayanto, A. N., Sandhyaduhita, P. I., Kasiyah, A., Ayuningtyas, D. (2015). Strategic hospital services quality analysis in Indonesia. Expert Systems with Applications, Vol. 42, No. 6, pp.3067-3078, Pergamon.

Hassali, M. A., Alrasheedy, A. A., Ab Razak, B. A., Al-Tamimi, S. K., Saleem, F., Haq, N. U., \& Aljadhey, H. (2014). Assessment of general public satisfaction with public healthcare services in Kedah, Malaysia. The Australasian Medical Journal, 7(1): 35-44.

Huang, J. A., Lai, C. S., Hu, J. S., \& Weng, R. H. (2014). The impact of market orientation on patient loyalty: The mediation of relationship quality. Service Business, 8(4), 499-515.

Izogo, E. E., \& Ogba, I. E. (2015). Service quality, customer satisfaction and loyalty in automobile repair services sector. International Journal of Quality \& Reliability Management, 32(3), 250-269.

Karassavidou, E. N., Papadopoulos C. T. (2009). Quality in NHS hospitals: no one knows better than patients. Meas Bus Excell, 13 (1) pp. 34-46.

Klementova, J., Zavadsky, J., \& Zavadska, Z. (2015). The measurement and evaluation of the service quality through customers' satisfaction. Procedia Economics and Finance, 26, 126-130.

Kotler, P., Keller, K., Ancarani, F., \& Costabile, M. (2016). Marketing Management. Pearson Education.

Lagrosen, Y., \& Lagrosen, S. (2016). Customer perceptions of quality-a study in the SPA industry. European Business Review, 28(6), 657-675.

Linqvist Leonardsen, A. C., Del Busso, L., Abrahamsen Grøndahl, V., Ghanima, W., Barach, P., \& Jels- nessJørgensen, L. P. (2016). A qualitative study of patient experiences of decentralized acute healthcare services. Scandinavian journal of primary health care, 34(3), 317-324.

Maria Stock, R., Jong, A. D., \& Zacharias, N. A. (2017). Frontline employees' innovative service behavior as key to customer loyalty: Insights into FLEs' resource gain spiral. Journal of Product Innovation Management, $34(2), 223-245$.

Martins, A. L., de Carvalho, J. C., Ramos, T., \& Fael, J. (2015). Assessing obstetrics perceived service quality at a public hospital. Procedia-Social and Behavioral Sciences, 181, 414-422.

McCall, S. J., Souers, R. J., Blond, B., \& Massie, L. (2016). Physician satisfaction with clinical laboratory services: a College of American Pathologists Q-Probes Study of 81 Institutions. Archives of pathology \& laboratory medicine, 140(10), 1098-1103.

Maroco, J. (2018). Análise Estatística - Com utilização do SPSS. Lisboa: Edições Silabo, Lda-Lisboa.

Mendes, I. A. C., Trevizan, M. A., de Godoy, S., Nogueira, P. C., Ventura, C. A. A. and Furlan, C. E. B. (2018). Expectations and perceptions of clients concerning the quality of care provided at a Brazilian hospital facility. Applied Nursing Research, Vol. 39, pp.211-216, W.B. Saunders [online] https://www.sciencedirect.com/journal/applied-nursing-research/vol/39/suppl/C; https://www.sciencedirect.com/science/article/pii/S0897189716301008.

Nekoei-Moghadam, M., \& Amiresmaili, M. (2011). Hospital services quality assessment: Hospitals of Kerman University of Medical Sciences, as a tangible example of a developing country. Int J Health Care Qual Assur, 24 (1) pp. 57-66

Parasuraman, A., Zeithaml, V. A., Berry, L. L. (1988). SERVQUAL: A multiple-item scale for measuring consumer perceptions of service quality. J Retailing, 64, 12-40.

Parsian, N., \& Dunning, A. T. (2009). Developing and validating a questionnaire to measure spirituality: A psychometric process. Global Journal of Health Science 1(1): 1-11.

Paul, P. D. (2003). What is the best approach for measuring service quality of periodontists? Clinical Research and Regulatory Affairs, Vol. 20, No.4, pp 457-468.

Pouragha, B. \& Zarei, E. (2016). The effect of outpatient service quality on patient satisfaction in teaching hospitals in Iran. Materia Socio-Medica, 28(1): 21.

Punnakitikashem R. N., Buavaraporn, P., \& Leelartapin, M. K. (2012). Health care service quality: Case example of a hospital with lean implementation. POMS 23rd Annual Conference, Chicago, IL, USA.

Qin, H., Prybutok, G. L., Prybutok, V. R. \& Wang, B. (2015). Quantitative comparisons of urgent care service providers. International Journal of Health Care Quality Assurance, Vol. 28, No. 6, pp.574-594, Emerald Group Publishing Ltd.

Rahimi, B., Safdari, R., Jebraeily, M. (2014). Development of hospital information systems: User participation and factors affecting it. Acta Inform Med: 22(6):398-401.

Ramsaran-Fowdar, R. R. (2005). Identifying health care quality attributes. Journal of Health and Human Services Administration, Vol. 27, No. 4, pp.428-443, SPAEF [online] https://jhhsa.spaef.org/article/551/IdentifyingHealth-Care-Quality-Attributes; https://www.jstor.org/stable/23211910?seq=1\#page_scan_tab_contents. 
Rashid, W. E. W. \& Jusoff, H. A. (2009). Service quality in health care setting. International Journal of Health Care Quality Assurance, Vol. 22, No. 5, pp.471-482, Emerald Group Publishing Limited.

Rasouli, O., \& Zarei, M. H. (2015). Monitoring and reducing patient dissatisfaction: A case study of an Iranian public hospital. Total Quality Management and Business Excellence, 27(5-6), 1-29.

Ricci, N. A., Wanderley, F. S., Oliveira, M. S., \& Rebelatto, J. R. (20 de 06 de 2009). O hospital-escola de São Carlos: análise do funcionamento por meio da satisfação dos usuários. p. 2.

Rostami, M., Ahmadian, L., Jahani, Y. \& Niknafs, A. (2019). The effect of patient satisfaction with academic hospitals on their loyalty. The International Journal of Health Planning and Management, Vol. 34, No. 1, pp.e726-e735, John Wiley \& Sons, Ltd.

Sadeh, E. (2017). Interrelationships among quality enablers, service quality, patients' satisfaction and loyalty in hospitals. The TQM Journal, 29(1), 101-117.

Sahoo, D., \& Ghosh, T. (2016). Healthcare role towards customer satisfaction in private healthcare. International Journal of Health Care Quality Assurance, 29(6), 600-613.

Shabbir, A., Malik, S. A. and Malik, S. A. (2016). Measuring patients' healthcare service quality perceptions, satisfaction, and loyalty in public and private sector hospitals in Pakistan'. International Journal of Quality $\&$ Reliability Management, Vol. 33, No. 5, pp.538-557, Emerald Group Publishing Limited.

Shabbir, S., Kaufmann, H. R., \& Shehzad, M. (2016). Service quality, word of mouth and trust: Drivers to achieve customer satisfaction. Scientific Research and Essays, 5(17), 2457-2462.

Sohail, S. M. (2003). Service quality in hospitals: more favourable than you might think. Manag Serv Qual, 13 (3) pp. 197-206.

Swies, R. J., Hashem, T. N., \& Ajarmah, B. S. (2017). The effect of 5Q model on patient's satisfaction in military hospitals in Jordan. International Journal of Productivity and Quality Management, 20(3), 273.

Tabibi, S. J., Gohari, M. R., Shahri, S. (2012). Assessment of health care services in outpatient clinics based on SERVQUAL model in hospitals of Tehran. Payavard Salamat, 5 (4) pp. 49-56.

Um, K. H., \& Lau, A. K. W. (2018). Healthcare service failure: how dissatisfied patients respond to poor service quality'. International Journal of Operations \& Production Management, Vol. 38, No. 5, pp.1245-1270, Emerald Publishing Limited.

Van De Ven, A. H. (2014). What matters most to patients? Participative provider care and staff courtesy. Patient Experience Journal, 1(1): 131-139.

Xesfingi, S., \& Vozikis, A. (2016). Patient satisfaction with the healthcare system: Assessing the impact of socioeconomic and healthcare provision factors. BMC Health Services Research, 16, 94.

Yi, Y., \& Nataraajan, R. (2018). Customer satisfaction in Asia. Psychology and Marketing, 35(6), 387- 391.

Yousapronpaiboon, K., \& Johnson, W. C. (2013). Measuring hospital out-patient service quality in Thailand. Leadership in Health Services, 26(4): 338-355.

Zaim, H., Bayyurt, N., \& Zaim, S. (2010). Service quality and determinants of customer satisfaction in hospitals: Turkish experience. The International Business \& Economics Research Journal, 9(5), 51 -58.

Züllich, D., Zimmering, M., Keil, T., \& Querfeld, U. (2012). Migration background and patient satisfaction in a pediatric nephrology outpatient clinic. Pediatric Nephrology, 27(8), 1309-1316. 